\title{
Prenatal testing and termination of future pregnancies in Arab mothers of children with severe defects: impact of Moslem cleric or physician on the decision making*
}

\author{
Lutfi Jaber ${ }^{1,2,3 \#, \text { Gabrielle J. Halpern }}{ }^{4}$, Samer Samara ${ }^{1}$
}

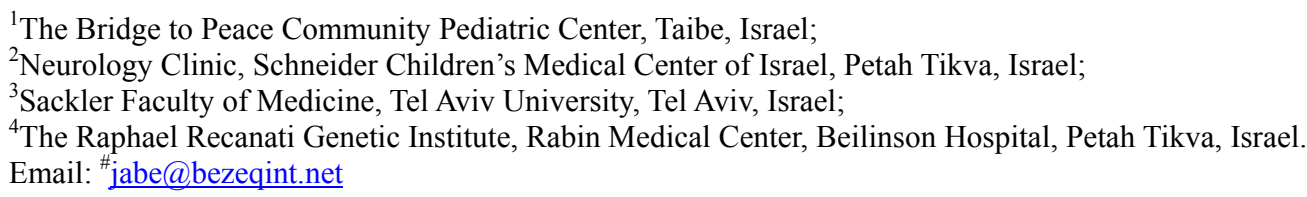

Received 8 September 2011; revised 14 October 2011; accepted 6 November 2011.

\section{ABSTRACT}

The authors investigated: 1) How many of 250 Israeli Arab mothers $(50 \%$ in consanguineous marriages) of babies with severe congenital anomalies had undergone prenatal testing during pregnancy, and how many had refused termination of pregnancy (TOP) when recommended; 2) Why TOP had been refused; 3 ) Attitudes regarding prenatal testing and TOP in future pregnancies; and 4) Whether the women would have changed their decision had they been able to talk to a Moslem cleric or Moslem doctor in addition to the regular personnel. Eighty seven (35\%) refused to even consider TOP, 55 (22\%) agreed to undergo TOP, and 87 (35\%) agreed provided the procedure would be performed before 120 days gestation. The remainder were undecided. Of 195 women, the addition of a Moslem religious cleric or physician to the Committee would influence $89(46 \%)$ and $55(28 \%)$, respectively, to change their opinion and agree to TOP, and $26(13 \%)$ and $10(5 \%)$, respectively, to change their opinion and agree to TOP prior to 120 days of gestation. The remainder either continued to refuse TOP or were undecided.

Keywords: Israeli Arab; Congenital Defects; Prenatal Testing; Termination of Pregnancy; Attitudes; Moslem Cleric

\footnotetext{
"Conflict of interest: All authors declare no conflict of interest. In particular none of the authors has received outside funding for the work involved in preparing this article. None of the authors or their immediate family has affiliations with or involvement in any companies or groups with a direct financial interest in the subject matter or materials discussed in this article.
}

\section{INTRODUCTION}

Congenital malformations and various genetic disorders are common and affect $3 \%-5 \%$ of all newborns. However, when children are examined in late childhood, the incidence is in the range of $6 \%-7 \%$ [1]. Congenital malformations are one of the most important causes of childhood morbidity and mortality [2-7].

The risk of birth of offspring with a congenital malformation to first cousin parents was 2.7-fold higher than that of progeny of unrelated parents [8]. In 1994 the rate of consanguineous marriages in the Israeli Arab community was $44 \%$, and of these, over $23 \%$ of marriages were between first cousins or double-first cousins [9]. A survey conducted in 2000 by Jaber et al. in selected regions of Israel showed a drop to $32 \%$ [10].

The aims of this study were:

1) To determine the percentage of women who gave birth to babies with severe congenital anomalies and who had undergone prenatal testing during pregnancy with the affected child;

2) To assess the percentage of mothers of children with severe congenital anomalies that had been diagnosed during the pregnancy, and where termination of pregnancy (TOP) had been recommended, but who had refused the procedure;

3) To ascertain why those women whose fetuses were found to have severe congenital anomalies and who refused TOP, chose to continue their pregnancies;

4) To discuss whether the women had taken into consideration the attitude of their spouse or other persons;

5) To discuss with the women what their attitudes towards prenatal testing and TOP would be in future pregnancies;

6) To investigate whether those women with severely affected fetuses who refused TOP would have changed 
their decision if they had been able to discuss the situation with either a Moslem cleric or a Moslem physician in addition to the regular personnel.

The information derived from this study is important and will assist us in designing a program of prenatal testing and counseling that is acceptable to Arab Moslem women and their families.

\section{METHODS}

This study was reviewed and approved by the Human Subjects Committee of the Beilinson Hospital, Rabin Medical Center. The study was conducted in the year 2007 and comprised families of children hospitalized in the various departments of the Schneider Children's Medical Center of Israel, or attending the outpatient clinics of the same hospital. Two hundred and fifty women were interviewed, of whom 244 were Moslem. The interviews were conducted by one of the authors (S.S., a qualified pediatrician) who is fluent in Arabic, and who filled in the data in a pre-structured questionnaire.

Initially, we discussed the diagnosis with the family and conducted a physical examination of the child. Information regarding the child's medical condition, family pedigree and occurrence of familial congenital malformations was obtained from the case file. Each family then answered a series of structured questions regarding their demographic details, socioeconomic status, and whether the women had undergone any tests, such as alphafetoprotein, amniocentesis, chorionic villus sampling (CVS), molecular genetic testing, or carrier screening for various genetic diseases either before or during the pregnancy. The next query was whether folic acid supplements had been taken both prior to and during the pregnancy. The women were then questioned regarding their attitudes when informed that because the fetus was severely affected, TOP was strongly recommended, and discussed with those who refused termination why they had done so. In light of having given birth to a severely affected child, the women were asked whether they would consider prenatal testing and TOP in future pregnancies, and whether they would consult their husband and consider his opinion. They were also questioned regarding family history, such as occurrence of congenital malformations. Finally, the women were asked whether, if they had been given the opportunity to discuss the situation either with a Moslem cleric or Moslem physician, they might, in light of such a discussion, have changed their minds and agreed to TOP.

\subsection{Dependent and Independent Variables}

In our study we considered certain dependent variables including the following prenatal tests:

1) Alpha-fetoprotein;

2) Nuchal translucency;
3) Early and late ultrasound examination;

4) Amniocentesis and CVS;

5) Carrier screening for common genetic diseases (Fragile X syndrome, cystic fibrosis and thalassemia);

6) Agreement to undergo TOP if recommended.

\subsection{Independent Variables}

1) Mother's age;

2) Mother's level of education;

3) Level of religiosity of the family;

4) Average family income;

5) Location of the family's home;

6) Number of offspring in the family;

7) Pregnancy monitoring by a private gynecologist, or within the framework of the medical insurance, or the Ministry of Health; and

8) The type of supplementary medical insurance.

\subsection{Criteria for Inclusion/Exclusion in the Study}

Children with severe defects or genetic disorders who were hospitalized or attended the various outpatient clinics were enrolled in the study. Children with mild defects or severe noncongenital or nongenetic disorders were excluded.

\subsection{Statistical Analysis}

The data were analyzed using BMDP Statistical Software (University of California, CA, USA). Discrete variables were compared, by groups, using Pearson's chi square test. A p-value of $\leq 0.05$ was considered significant [11].

\section{RESULTS}

The demographic characteristics of the 250 women interviewed are shown in Table 1. One hundred seventysix $(70 \%)$ women were under 35 years of age. The remainder were 35 years of age, or older, and were primipara. One hundred twenty-five women (50\%) were married to a relative, of whom $81(65 \%)$ were married to a first cousin and $44(35 \%)$ to a more distant relative. Eighty (32\%) of the 250 women knew during the pregnancy that the fetus had an abnormality; of these, 71 (28.4\%) were advised to undergo TOP but all refused, and the remainder were not advised to terminate their pregnancies.

Various prenatal tests, as aforementioned, were recommended to the women by the nurses at the Well-Baby Clinics and Table 2 shows the number of women who underwent these tests.

\subsection{Attitudes of the Women Regarding TOP in Future Pregnancies According to Different Variables}

Eighty seven women (35\%) refused to consider TOP under any circumstances in future pregnancies. Fifty five 
Table 1. Demographic characteristics.

\begin{tabular}{|c|c|}
\hline Demographic characteristics & Number of families (\%) \\
\hline \multicolumn{2}{|l|}{ Area of residence } \\
\hline North & $49(19.7)$ \\
\hline Center & $166(66.7)$ \\
\hline South & $34(13.6)$ \\
\hline \multicolumn{2}{|l|}{ Age of child (years) } \\
\hline $0-1$ & $108(43.2)$ \\
\hline $1-2$ & $36(14.4)$ \\
\hline $2-3$ & $28(11.2)$ \\
\hline $3-4$ & $24(9.6)$ \\
\hline $4-5$ & $18(7.2)$ \\
\hline $5-6$ & $5(2.0)$ \\
\hline over 6 & $31(12.4)$ \\
\hline \multicolumn{2}{|l|}{ Religion } \\
\hline Moslem & $243(97.6)$ \\
\hline Others & $6(2.4)$ \\
\hline \multicolumn{2}{|l|}{ Religiosity of Moslems } \\
\hline Secular & $82(33.0)$ \\
\hline Traditional & $77(31.0)$ \\
\hline Religious & $9(3.6)$ \\
\hline Not known & $81(32.4)$ \\
\hline \multicolumn{2}{|l|}{ No. children in family } \\
\hline 1 & $36(14.4)$ \\
\hline 2 & $54(21.6)$ \\
\hline 3 & $62(24.8)$ \\
\hline 4 & $38(15.2)$ \\
\hline more than 4 & $60(24.0)$ \\
\hline \multicolumn{2}{|l|}{ Age of mother (years) } \\
\hline under 35 & $176(71.0)$ \\
\hline 35 and over & $72(29.0)$ \\
\hline \multicolumn{2}{|l|}{ Education } \\
\hline Primary school & $76(31.0)$ \\
\hline Secondary school & $111(45.3)$ \\
\hline Higher education & $58(23.7)$ \\
\hline \multicolumn{2}{|l|}{ Monthly income } \\
\hline Less than 6000 NIS (US\$1500) & $219(87.6)$ \\
\hline More than 6000 NIS & $31(12.4)$ \\
\hline \multicolumn{2}{|l|}{ Socioeconomic status } \\
\hline Low & $192(77.7)$ \\
\hline Middle & $44(17.8)$ \\
\hline High & $11(4.5)$ \\
\hline Prenatal folic acid Yes & $35(14)$ \\
\hline Family has basic health insurance Yes & $250(100)$ \\
\hline $\begin{array}{l}\text { Family has supplementary } \\
\text { health insurance Yes }\end{array}$ & $177(70.8)$ \\
\hline Consanguinity between parents Yes & $\begin{array}{c}49.8 \% \\
\text { (32.4\% are first } \\
\text { cousins) }\end{array}$ \\
\hline
\end{tabular}

Table 2. Number (\%) of women who underwent the recommended prenatal tests.

\begin{tabular}{cc}
\hline Test & $\begin{array}{c}\text { Number (\%) who } \\
\text { performed test }\end{array}$ \\
\hline Carrier screening for thalassemia & $250(100)$ \\
Late ultrasound examination & $235(94)$ \\
Triple test & $203(81)$ \\
Early ultrasound examination & $202(81)$ \\
Fetal echocardiography & $72(29)$ \\
Amniocentesis or chorionic villus sampling & $31(12)$ \\
Nuchal translucency & $19(8)$ \\
Carrier screening for common genetic & $0 *$ \\
diseases apart from thalassemia &
\end{tabular}

*When the women were pregnant with the affected children (during the 1990 's) they were unaware that genetic screening tests for diseases besides thalassemia were available.

(22\%) agreed to TOP, and 87 (35\%) agreed only on condition that TOP would be performed prior to 120 days gestation. Twenty one women (8\%) were undecided.

There were no differences in the attitudes of the women regarding TOP according to area of residence, religiosity, years of marriage, levels of education of the couple, monthly income, socioeconomic status, sex of the affected fetus, and whether or not the woman had taken folic acid supplements. Also irrelevant was whether or not the woman had undergone ultrasound examination for nuchal translucency, fetal echocardiography, or if she was aware that her fetus suffered from a congenital anomaly. Moreover, whether or not the woman had received genetic counseling made no difference to her attitude, and having given birth previously to one or more affected children did not influence her in any way either.

One hundred and forty $(69.5 \%)$ of 203 women responded positively to the question whether other individuals in the family suffered from a congenital malformation. No association was found among those mothers with more than one affected child and their attitude regarding TOP.

However, an association was found between those women who agreed to perform the triple test and those who were willing to undergo TOP at any stage of gestation in the event of a severely abnormal fetus $(p>0.01)$. A positive association was also found among the women who underwent early ultrasound examination $(\mathrm{p}>0.06)$ and the extended ultrasound $(\mathrm{p}>0.025)$. Those who underwent amniocentesis were also more likely to agree to TOP if recommended $(\mathrm{p}>0.017)$.

The main reason for refusal to terminate a pregnancy when this was considered to be medically advisable was religious objections (49.6\%). On the other hand, in $18 \%$ of cases the couple was unaware that the fetus was af- 
fected, either because they had not been referred for further investigation, or because they only sought advice at an already late stage in the pregnancy. In $2.8 \%$ of cases the couple did not trust the tests, and in $29.6 \%$ of cases the reason was unclear.

One hundred and three (48.1\%) out of 214 women responded positively to the question whether they consulted their husband regarding TOP, and strongly considered his opinion.

\subsection{Effect of Including a Moslem Religious Cleric or a Senior Moslem Physician in the Hospital Committee on the Woman's Decision Whether or Not to Undergo TOP}

In our cohort, 55 (22\%) women would agree to TOP, 87 (35\%) would refuse and 87 (35\%) would agree only on condition that it would be performed prior to 120 days of gestation. When we excluded the 55 women who agreed to TOP, the remaining $195(78 \%)$ were asked whether the addition of a Moslem religious cleric or Moslem physician to the Hospital Committee for TOP would influence them to change their opinion (Table 3): 89 (46 $\%$ ) said they would now agree if it were recommended, $74(38 \%)$ said that this would make no difference and they would still refuse, 26 (13\%) agreed only on condition that it would be carried out prior to 120 days of gestation and $6(3 \%)$ were still undecided. When we asked what the effect would be of including a senior Moslem physician in the Committee $55(28 \%)$ said they would then agree to TOP if recommended, 128 (66\%) said they would not change their opinion and would continue to refuse, and $10(5 \%)$ would agree only on condition that it would be carried out prior to 120 days gestation; 2 (1\%) were still undecided (Table 3).

Table 3. The effect of a Moslem cleric or Moslem physician on the decision-making process to undergo termination of pregnancy (TOP).

\begin{tabular}{cccc}
\hline & $\begin{array}{c}\text { No intervention } \\
\text { No. }(\%)\end{array}$ & $\begin{array}{c}\text { Intervention } \\
\text { Cleric } \\
\text { No. }(\%)\end{array}$ & $\begin{array}{c}\text { Intervention } \\
\text { Physician } \\
\text { No. }(\%)\end{array}$ \\
\hline $\begin{array}{c}\text { Agreed to TOP } \\
\text { Refused TOP }\end{array}$ & $85(22)$ & $89(46)$ & $55(28)$ \\
$\begin{array}{c}\text { Agreed to TOP } \\
\text { at less than 120 days } \\
\text { gestation }\end{array}$ & $87(35)$ & $26(13)$ & $10(5)$ \\
Undecided & $21(8)$ & $6(3)$ & $28(66)$ \\
Total & & & $195(100)$ \\
\hline
\end{tabular}

\section{DISCUSSION}

In our cohort, $50 \%$ of the women were married to a relative, of whom $32.4 \%$ were married to a first cousin. These figures show that the rate of consanguineous marriages among the families with genetic disorders was considerably higher than average in the Israeli Arab population which was $32 \%$ [10].

This study indicates that among Arab Moslem mothers of severely affected children there is a high degree of opposition to TOP in the event of a subsequent severely affected fetus, even when the existing children were hospitalized for prolonged periods of time, or had undergone major surgical procedures. In general, those women who underwent any or all of the triple test, early ultrasound examination or the extended ultrasound examination were more willing to agree to consider TOP, as were women who underwent amniocentesis.

Support for abortion and the belief that life begins at ensoulment is based primarily on quotations from the Qur'an. The following verse discusses the different stages (semen, blood clot, bones and flesh) of fetal development: "Man We did create from quintessence (of clay), then We placed him as (a drop of) sperm in a place of rest, firmly fixed, then we made the sperm into a clot of congealed blood, then of that clot We made a (fetus) lump, then we made out of that lump bones and clothed the bones with flesh, then We developed out of it another creature. So, blessed be Allah the Best to create [12].

According to Qur'anic verses and Moslem prophetic tradition, the fetus becomes "ensouled" at 120 days gestation. However, abortion after 120 days is considered a criminal offense and is prohibited by all Islamic scholars [13].

In our study, almost half of those women who refused TOP, did so because of religious objections. The women were informed that Moslem religious teaching allowed TOP within the first 120 days after conception. When all the women who had refused were asked whether the presence of a Moslem religious cleric or a senior Moslem physician on the Committee would influence their decision, their responses indicated that from the religious angle they would trust the opinion of a religious cleric more than $1^{1 / 2}$-fold that of a physician.

In a study conducted in Saudi Arabia to assess the attitude of Saudi families, affected with hemoglobinnopathies, towards prenatal screening and abortion and the influence of religious ruling, it was found that the Fatwa did change the attitude of almost half of those who initially refused the idea of abortion [14].

In a previous study conducted by Jaber et al. [15], 231 Arab women, who had given birth to healthy babies 3 days prior to the interview, were asked their opinion on TOP in the event of a severely affected fetus, and 83 
(36\%) said they would agree to TOP, $131(56.7 \%)$ said they would not, and $17(7.3 \%)$ were undecided. In the present study, $57 \%$ of the women agreed to TOP, of whom $35 \%$ agreed only on condition that it would be carried out prior to 120 days gestation. Such a distinction was not made among the group of women in the earlier study [15].

Zahed et al. conducted two studies in Lebanon, the first [16] involving 83 couples at risk for a hemoglobin disorder, mainly beta-thalassemia, and the second [17] comprising 90 couples at risk for various genetic disorders, in order to assess their acceptance of prenatal diagnosis and the variables that may influence their choice. In each survey, of those who refused, a large majority said that the reason for their refusal was because of religious conviction against TOP [16].

Tsianakas and Liamputtong found that Moslem women living in Australia despite their doubts, tended to accept prenatal testing as they believed it was a routine part of antenatal care and confirmed their perceptions of being a "normal mother" who should accept their doctor's advice [18].

Ahmed et al. in a study of pregnant Pakistani women in the North of England, found that their attitudes towards prenatal diagnosis and TOP for thalassemia were influenced by various factors, and therefore their religion should not be taken as the main determinant of their stance for or against TOP [19]. In another survey [20] the same authors investigated the attitudes of the participants to discussing the question of TOP for thalassemia with a religious cleric and found that they would not consult a religious leader for advice on prenatal diagnosis and TOP. They said that this was because religious leaders were more likely to provide biased opinions than advice based on medical knowledge. This stands in direct contrast to our findings, which showed that nearly half of the Israeli Arab women we interviewed, who had originally refused to consider TOP, did agree to consider this after consultation with a Moslem cleric, whereas only about a quarter of those women would change their minds and agree after consultation with a Moslem physician.

Our survey included all families of children with single or multiple defects, or genetic disorders that were severe enough for the children to require hospitalization either for prolonged or recurrent periods of time on several occasions, or both. In many cases major surgery was also required on one or more occasions.

It should be stressed that the limitation of this study was that we did not include a control group.

\section{RECOMMENDATIONS}

Further strategies should be considered in order to reduce even more the frequency of consanguineous mar- riages.

\subsection{Before Pregnancy}

In families where there is a high probability that both spouses may be carriers of a particular disease, genetic testing for that condition, if available, should be performed.

In cases where a specific condition or conditions are prevalent in a village and the causative gene(s) are not yet known, identification of the gene(s) and mutations responsible will enable development of preventive programs as aforementioned. It is important to conduct the counseling and blood-drawing sessions within the villages as the convenience to the residents will encourage participation in the programs; they may be far less willing to participate if they have to travel a long way to the hospital $[21,22]$.

It may also be useful if the Hospital Committees for TOP, which currently comprise a gynecologist, neonatologist and a social worker, were to ask the Moslem couples appearing before them whether they would consider it valuable to include a Moslem cleric in order to assist them with any queries or doubts of a religious nature that they may have, and, if they agree, to invite such a cleric to sit on the committee during the interview.

In specific cases where both spouses are carriers of a specific condition, preimplantation genetic diagnosis could be considered if and when feasible.

\subsection{During Pregnancy}

Certain examinations should be considered and a full explanation of the purpose and nature of the tests should be given before the woman is asked whether she agrees to undergo them. The tests offered include CVS, nuchal translucency, triple test, amniocentesis, and targeted ultrasound.

\section{REFERENCES}

[1] Shepard, T.H. (1986) Human teratogenicity. Advances in Pediatrics, 33, 225-268.

[2] Naderi, S. (1979) Congenital abnormalities in newborns of consanguineous and nonconsanguineous parents. $\mathrm{Ob}$ stetrics and Gynecology, 53, 195-199.

[3] Magnus, P., Berg, K. and Bjerkedal, T. (1985) Association of parental consanguinity with decreased birth weight and increased rate of early death and congenital malformations. Clinical Genetics, 28, 335-342.

doi:10.1111/j.1399-0004.1985.tb00407.x

[4] Shami, S.A., Schmitt, L.H. and Bittles, A.H. (1989) Consanguinity related prenatal and postnatal mortality of the populations of seven Pakistani Punjab cities. Journal of Medical Genetics, 26, 267-271.

doi:10.1136/jmg.26.4.267

[5] Bittles, A.H., Mason, W.M., Greene, J., et al. (1991) Re- 
productive behavior and health in consanguineous marriages. Science, 252, 789-794.

doi:10.1126/science.2028254

[6] Zlotogora, J. (1997) Autosomal recessive diseases among Palestinian Arabs. Journal of Medical Genetics, 34, 765766. doi:10.1136/jmg.34.9.765

[7] Jaber, L., Halpern, G.J. and Shohat, M. (1998) The impact of consanguinity worldwide. Community Genetics, 1, 12-17. doi:10.1159/000016130

[8] Jaber, L., Merlob, P., Bu, X., et al. (1992) Marked parental consanguinity as a cause for increased major malformations in an Israeli Arab community. American Journal of Medical Genetics, 44, 1-6. doi:10.1002/ajmg.1320440102

[9] Jaber, L., Bailey-Wilson, J.E., Haj-Yehia, M., et al. (1994) Consanguineous matings in an Israeli-Arab community. Archives of Pediatrics and Adolescent Medicine, 148, 412-415.

[10] Jaber, L., Halpern, G.J. and Shohat, T. (2000) Trends in the frequencies of consanguineous marriages in the Israeli Arab community. Clinical Genetics, 58, 106-110. doi:10.1034/j.1399-0004.2000.580203.x

[11] Dixon, W.J. (1993) BMDP Statistical Software. University of California Press, Berkeley.

[12] Hessini, L. (2007) Abortion and Islam: Policies and practice in the Middle East and North Africa. Reproductive Health Matters, 15, 75-84. doi:10.1016/S0968-8080(06)29279-6

[13] Shaikh, S. (2003) Family planning, contraception and abortion in Islam: Undertaking Khilafah: Moral agency, justice and compassion. In: Maguire, D., Ed., Sacred Choices: The Case for Contraception and Abortion in World Religions, Oxford University Press, Oxford, 1-4.

[14] Alkuraya, F.S. and Kilani, R.A. (2001) Attitude of Saudi families affected with hemoglobinopathies towards prenatal screening and abortion and the influence of religious ruling (Fatwa). Prenatal Diagnosis, 21, 448-451. doi: $10.1002 / \mathrm{pd} .76$
[15] Jaber, L., Dolfin, T., Shohat, T., et al. (2000) Prenatal diagnosis for detecting congenital malformations: Acceptance among Israeli Arab women. Israel Medical Association Journal, 2, 346-350.

[16] Zahed, L. and Bou-Dames, J. (1997) Acceptance of firsttrimester prenatal diagnosis for the haemoglobinopathies in Lebanon. Prenatal Diagnosis, 17, 423-428. doi:10.1002/(SICI)1097-0223(199705)17:5<423::AID-P D68>3.0.CO;2-P

[17] Zahed, L., Nabulsi, M., Bou-Ghanim, M., et al. (1999) Acceptance of prenatal diagnosis for genetic disorders in Lebanon. Prenatal Diagnosis, 19, 1109-1112. doi:10.1002/(SICI)1097-0223(199912)19:12<1109::AID -PD708>3.0.CO;2-V

[18] Tsianakas, V. and Liamputtong, P. (2002) Prenatal testing: The perceptions and experiences of Muslim women in Australia. Journal of Reproductive and Infant Psychology, 20, 7-24. doi:10.1080/02646830220106767

[19] Ahmed, S., Green, J.M. and Hewison, J. (2006) Attitudes towards prenatal diagnosis and termination of pregnancy for thalassaemia in pregnant Pakistani women in the North of England. Prenatal Diagnosis, 26, 248-257. doi:10.1002/pd.1391

[20] Ahmed, S., Atkin, K., Hewison, J., et al. (2006) The influence of faith and religion and the role of religious and community leaders in prenatal decisions for sickle cell disorders and thalassaemia major. Prenatal Diagnosis, 26, 801-809. doi:10.1002/pd.1507

[21] Zlotogora, J., Barges, S., Bisharat, B., et al. (2006) Genetic disorders among Palestinian Arabs. 4: Genetic clinics in the community. American Journal of Medical Genetics, 140, 1644-1646. doi:10.1002/ajmg.a.31342

[22] Basel-Vanagaite, L., Taub, E., Halpern, G.J., et al. (2007) Genetic screening for autosomal recessive nonsyndromic mental retardation in an isolated population in Israel. European Journal of Human Genetics, 15, 250-253. doi:10.1038/sj.ejhg. 5201750 